\title{
УСТОЙЧИВЫЕ ПРОДОВОЛЬСТВЕННЫЕ СИСТЕМЫ: МИРОВАЯ ПРАКТИКА И ОПЫТ ГОСУДАРСТВ - ЧЛЕНОВ ЕВРАЗИЙСКОГО ЭКОНОМИЧЕСКОГО СОЮЗА
}

\section{Н.В. Киреенко}

Рассмотрены теоретические основы формирования устойчивой продовольственной системы, включающие эволюцию научных концепций, методологические принципы и комплексную классификацию основных ее составляющих. Обоснованы современные тенденции развития системы продовольственного обеспечения в государствах - членах Евразийского экономического союза на национальном и наднациональном уровнях. На основе международного опыта определены ключевые направления формирования устойчивой продовольственной системы в странах Союза на краткосрочную и долгосрочную перспективу.

Ключевые слова: устойчивость, национальная продовольственная система, мировая продовольственная система, концепция устойчивого развития, Евразийский экономический союз.

JEL-классификация: F10, F47, Q01, Q13, Q17, Q18.

DOI: $10.46782 / 1818-4510-2021-1-70-86$

Материал поступил 11.01.2021 2.

Лауреатом Нобелевской премии мира 2020 г. стала Всемирная продовольственная программа $\mathrm{OOH}$ (World Food Programme WFP), основанная в 1961 г. как орган по продовольственной помощи и являющаяся крупнейшей в мире гуманитарной организацией ${ }^{1}$. Данная награда присуждена WFP за усилия в борьбе с голодом, экономический и социальный вклад в улучшение условий жизни населения, пострадавшего от военных действий, природных и техногенных катастроф, а также за информационно-пропагандистскую деятельность по предотвращению использования голода как средства ведения войны и конфликтов. Признание мировым сообществом показало: проблема обеспечения продовольственной безопасности, ведения сельскохозяйственного и пищевого производства на национальном и мировом уровнях остается актуальной и в третьем десятилетии XXI в.

Объем мирового продовольствия оценивается в 8 трлн долл. США и равен примерно $10 \%$ мирового ВВП. Функционирование современной продовольственной системы основывается на концепции устойчивого развития, включающей экономические, соци-

${ }^{1}$ URL: https://ru.wfp.org альные и экологические вопросы и предусматривающей комплекс мер, направленных на оптимальное использование ограниченных ресурсов и ресурсосберегающих технологий. Исследования показывают, что термин «устойчивое развитие» ${ }^{2}$ введен Всемирной комиссией $\mathrm{OOH}$ по окружающей среде и развитию (1987 г.), а обязательства стран по его достижению определены декларацией Повестки дня на XXI век, принятой на Конференции ООН по окружающей среде и развитию (июнь 1992 г., Рио-де-Жанейро). В этом же году ООН учредила комиссию, которая приняла Программу работы по показателям (индикаторам) устойчивого развития, включающую рекомендации правительствам государств по принятию стратегических управленческих решений (1995 г.). В развитие этого странами принята Декларация тысячелетия ООН (2000 г.), а позже Повестка дня в области устойчивого развития на период до 2030 года $^{3}$ (2015 г.). Сегодня данные подхо-

\footnotetext{
2 Устойчивое развитие - это развитие, которое удовлетворяет потребности настоящего времени, но не ставит под угрозу способность будущих поколений удовлетворять свои собственные потребности.

${ }^{3}$ Официально известная как Преобразование нашего мира: повестка дня в области устойчивого развития на период до 2030 года.
}

* Киреенко Наталья Владимировна (natallia_kireenko@mail.ru), доктор экономических наук, профессор, Белорусский государственный аграрный технический университет (г. Минск, Беларусь). 
ды используются в отношении разных сфер и видов экономической деятельности на национальном уровне.

Теоретические и прикладные проблемы формирования и функционирования продовольственных систем рассмотрены в трудах зарубежных ученых, которые проводили исследования по разнообразию путей и механизмов решения продовольственной проблемы, обеспечению стабильности сельскохозяйственного производства и сбыта продукции на внутреннем рынке, обоснованию комплекса деструктивных факторов, влияющих на устойчивое развитие национальных продовольственных систем, включая демографические вопросы, изменение климата, политическую нестабильность, конфликты и неуклонный рост нагрузки на земельные, водные ресурсы, биоразнообразие и др. (Ericksen, 2008; Ingram, 2011; Fuglie, 2018; Ghisellini, Cialani, Ulgiati, 2016; Sobal, Kettel, Bisogni, 1998; Weltzien, 2016).

Многие направления развития теории и практики устойчивости продовольственных систем нашли отражение в исследованиях российских ученых. Ими обоснованы теоретические и методологические аспекты, а также направления перехода к устойчивым продовольственным системам в Российской Федерации и на уровне ее регионов, внедрения цифровых, экологических и инновационных технологий для повышения результативности агроиндустрии на основе комплексного подхода в целях эффективного функционирования продуктовых рынков ${ }^{4}$ (Акимова, Коваленко, 2016; Баринова, Земцов, 2019; Белоусов, 2013; Большаков, 2011; Добросоцкий, 2019; Коваленко, 2017; Фролов, 2011; Берг, Большаков, Гольдштейн, Попков, 2007; Шагайда, Узун, 2019; Янбых, 2011).

Различные аспекты формирования продовольственной системы в Республике Беларусь рассматривались на законодательном и научном уровнях. Так, стратегические направления были определены в рамках Национальной стратегии устойчивого развития

4 Бобылев С.Н., Гирусов Э.В., Перелет Р.А. 2004. Экономика устойчивого развития: учебное пособие. Москва: Издательство «Ступени». 302 с.; Марфенин Н.Н. 2006. Устойчивое развитие человечества: учебник. Москва: Издательство МГУ. 612 с.
Республики Беларусь ${ }^{5}$, Национальной стратегии устойчивого развития Республики Беларусь на период до 2020 года $^{6}$, Национальной стратегии устойчивого социально-экономического развития Республики Беларусь на период до 2030 года ${ }^{7}$ К Концепции национальной продовольственной безопасности Республики Беларусь ${ }^{8}$, Доктрины национальной продовольственной безопасности Республики Беларусь до 2030 года9. В трудах В.Г. Гусакова (2020), 3.М. Ильиной $(2012,2013)$ представлены роль и значение устойчивых систеи в обеспечении национальной продовольственной безопасности, обоснованы особенности функционирования в современных условиях; О.С. Шимовой ${ }^{10}$ - теоретические основы формирования современной модели мирового развития, научно-методические подходы к выработке критериев и показателей для измерения степени устойчивости социо-эколого-экономических систем; В.И. Бельского (2018), И.А. Войтко (2020) экономические механизмы государственного регулирования агропромышленного комплекса, включая продовольственные системы; М.С. Байгот (2020), А.П. Шпака, Н.В. Киреенко, Л.Н. Байгот, С.А. Кондратенко (2015) перспективы стратегического развития агропродовольственной сферы на основе повышения эффективности внешней торговли и системы продвижения продукции сельского хозяйства и обрабатывающей промышленности Республики Беларусь; В.Г. Гусакова, А.В. Пилипука (2018) - направления конкурентоустойчивого развития производства продуктов здорового питания на предприятиях пищевой промышленности Беларуси; С.А. Кондратенко (2019) - научные предложения по устойчивому развитию регионального агропродовольственного комплекса; Л.В. Лагодич (2015) - теоретические и методологические основы измерения устойчиво-

${ }^{5}$ URL: https://normativka.by/lib/document/500014482

6 URL: https://un.by/images/library/thematicpublications/sustainable-development/OON_sMall_Rus.pdf

7 URL: http://www.economy.gov.by/uploads/files/ NSUR2030/Natsionalnaja-strategija-ustojchivogo-sotsialnoekonomicheskogo-razvitija-Respubliki-Belarus-na-period-do2030-goda.pdf

8 URL: https://pravo.by/document/?guid $=3961 \&$ p $0=$ C21400252

${ }^{9}$ URL: https://mshp.gov.by/documents/plant/ dccea377014340f4.html

${ }^{10}$ Шимова О.С. 2017. Устойчивое развитие: учебник. Минск: БГЭУ. 395 с. 
го развития экономических систем и методика комплексной оценки устойчивости развития национального продовольственного рынка. Наряду с этим Н.В. Киреенко и С.А. Кондратенко обосновали рыночные (транспарентные) инструменты оценки продовольственных ресурсов на внутреннем рынке, основанные на систематизации действующего законодательства в области устойчивого развития региональных продуктовых рынков ${ }^{11}$. Научные исследования и практическая работа проводятся и в разрезе отдельных продуктовых сегментов, что позволяет выполнять оперативный мониторинг и выделять ключевые направления развития продовольственной системы на национальном и областном уровнях (Гусаков, Шпак, Киреенко, Байгот, Кондратенко, Ахрамович, Енчик, Карпович, Лобанова, Гусаков, Макуценя, Пашкевич, 2018; Гануш, 2019; Шпак, Киреенко, Кондратенко, Енчик, Лобанова, Стешиц, Мицкевич, Косова, 2018).

Вместе с тем, подчеркивая значимость данных разработок, необходимо отметить, что в настоящее время сельскохозяйственные и продовольственные системы мира не в полной мере отвечают требованиям устойчивости. Несмотря на увеличение показателей наличия продовольствия в мире, количество людей, страдающих от голода, за последние 40 лет существенно не изменилось. На сегодняшний день насчитывается 820 млн голодающих, что делает еще более актуальной огромную задачу по ликвидации голода к 2030 г. ${ }^{12}$ Пандемия COVID-19 показала, что для обеспечения достаточности продуктов питания на внутреннем рынке необходимо формирование устойчивых продовольственных систем, базирующихся на:

достижении объемов и структуры производства продукции растениеводства, животноводства и их переработки, позволяющих сбалансировать внутренний спрос и предложение по важнейшим видам сельскохозяйственной продукции и продуктов питания;

${ }_{11}$ Киреенко Н.В., Кондратенко С.А. 2016. Рекомендаиии по оценке и упреждению потенциала угроз в продовольственной сфере Республики Беларусь (с учетом мирового опыта). Минск: Институт системных исследований в АПК НАН Беларуси. 91 с.

${ }^{12}$ URL: http://www.fao.org/3/ca5162ru/ca5162ru.pdf насыщении национального рынка качественными продуктами питания собственного производства в достаточном объеме и по приемлемым ценам с учетом экономической доступности;

развитии внутренней и внешней производственно-сбытовой и торговой инфраструктуры агропродовольственного сегмента страны.

Целью данной статьи является анализ мировой практики формирования устойчивых продовольственных систем, современных тенденций развития и определение направлений их совершенствования в государствах - членах Евразийского экономического союза в условиях влияния внешних и внутренних угроз. Задачи исследования: обосновать научные концепции, выявить теоретические и методологические особенности построения устойчивой продовольственной системы; проанализировать современные тенденции развития системы продовольственного обеспечения в государствах - членах Евразийского экономического союза; на основе международного опыта определить ключевые направления формирования устойчивой продовольственной системы Союза на краткосрочную и долгосрочную перспективу.

\section{Эволюция научных концепций формирования и развития продовольственной системь}

В научном контексте продовольственная система рассматривается в узком и широком смысле слова. В первом случае трактуется как эффективное взаимодействие «человек - окружающая среда» (Ericksen, 2008; Ingram, 2011); во втором - это концепция продовольственной системы, или продовольственной и пищевой системы (Sobal, Khan, Bisogni, 1998). В таком понимании она связана со множеством других систем (энергетическими, транспортными, складскими, торговыми и др.), сталкивается с различными рыночными барьерами и ограничениями. Материальной ее основой являются: промышленность, производящая средства производства; сельское хозяйство, производящее сельскохозяйственное сырье; переработка и сбыт готового продовольствия. В совокупности это взаи- 
мосвязанные сферы, которые образуют единое целое, где главенствующая роль принадлежит потреблению. Как справедливо отмечал Д. Сакс (1994), «основная идея рыночной экономики сводится к тому, что люди осуществляют свой личный выбор - что купить, где работать, как разместить сбережения, а предприятия под этот выбор подстраиваются».

В развитие этого нами предлагается рассматривать продовольственную систему как объект управления, который включает взаимосвязанные подсистемы (кадровая, материально-техническая, технологическая, информационная, финансовая, научная и др.), а также виды экономической деятельности, связанные с производством, переработкой, распределением и потреблением сельскохозяйственной продукции и продуктов питания, объединенных едиными принципами. При этом последние представляют собой совокупность четко сформулированных потребностей покупателей, составляющих потенциала неудовлетворенного спроса и включают:

- ориентацию производственно-сбытовой и научно-исследовательской деятельности субъектов АПК на рынк;

- использование дифференцированного подхода к производству и реализации сельскохозяйственной продукции на внутреннем и внешнем рынках;

- внедрение инноваций в сферу производства, переработки, хранения, транспортировки и складирования продовольствия;

- гибкое реагирование на изменение потребностей и запросов оптовых и розничных потребителей сельскохозяйственной продукции;

- постоянное и целенаправленное воздействие на производственно-сбытовую цепочку в сфере продовольствия;

- ориентацию на длительный период времени.

В современных условиях развития сельскохозяйственного и пищевого производства, наличия форс-мажорных обстоятельств на продуктовых рынках, изменения потребностей потребителей аграрной продукции и их покупательской способности усиливается значимость устойчивого функционирования продовольственной систе- мы. Непосредственно категория «устойчивость» характеризует способность объекта сохранять стойкость, постоянство, неподверженность риску потерь и убытков ${ }^{13}$. В настоящее время существует значительное количество определений категории «устойчивая продовольственная система» (далее УПС). В то же время данные подходы направлены на обеспечение продовольственной безопасности и питания для всего населения таким путем, при котором не ставится под угрозу экономическая, социальная и экологическая основы, необходимые для обеспечения продовольственной безопасности и питания будущих поколений $^{14}$. В развитие этого Продовольственная и сельскохозяйственная Организация Объединенных Наций (FAO) выделяет следующие методологические подходы поэтапного создания УПС:

1) проведение интенсификации производственных систем, включая климатически оптимизированное сельское хозяйство, устойчивые продовольственные производственно-сбытовые цепочки, факторы полноценного питания, предусматривающие рост продуктивности на единицу угодий;

2) формирование агроэкологических систем и связанных с ними подходов (органическое сельское хозяйство, агролесоводство и перманентное сельское хозяйство), обеспечивающие снижение объемов вводимых ресурсов и применение диверсификации для улучшения состояния окружающей среды и здоровья людей.

Выполненные исследования позволили выделить и сформулировать научные концепции развития продовольственной системы, основанные на взаимодействии ее участников, учитывающие тенденции и направления мирового аграрного бизнеса, уровень использования инновации в сфере производства, переработки, хранения,

\footnotetext{
13 Продовольственная безопасность. Термины и понятия: энциклопедический справочник. 2008. Минск: Белорусская наука.

14 Agriculture in the European Union - Statistical and Economic Information - Report 2010. Luxembourg: Publications Office of the European Union; High Level Panel of Experts on Food Security and Nutrition (HLPE). 2014. Food losses and waste in the context of sustainable food systems. A report by the High Level Panel of Experts on Food Security and Nutrition of the Committee on World Food Security. Rome: FAO.
} 
Таблица 1

Эволюция научных концепций формирования и развития устойчивой продовольственной системы

\begin{tabular}{|c|c|c|c|c|c|c|c|}
\hline \multirow{3}{*}{$\begin{array}{c}\text { Сеть, система, } \\
\text { сектор, цепочка, } \\
\text { время } \\
\text { возникновения }\end{array}$} & \multicolumn{7}{|c|}{ Основные субъекты продовольственной системы } \\
\hline & \multirow{2}{*}{\begin{tabular}{|} 
Производитель \\
сельскохо - \\
зяйственного \\
сырья
\end{tabular}} & \multirow{2}{*}{$\begin{array}{c}\text { Организации } \\
\text { по доставке } \\
\text { сельскохо - } \\
\text { зяйствен- } \\
\text { ного сырья }\end{array}$} & \multicolumn{3}{|c|}{$\begin{array}{c}\text { Предприятия - потребитель } \\
\text { сельскохозяйственного сырья }\end{array}$} & \multirow{2}{*}{$\begin{array}{c}\text { Организа- } \\
\text { ции по } \\
\text { доставке } \\
\text { продук- } \\
\text { тов } \\
\text { питания }\end{array}$} & \multirow{2}{*}{$\begin{array}{c}\text { Потреби- } \\
\text { тель } \\
\text { продук- } \\
\text { тов } \\
\text { питания }\end{array}$} \\
\hline & & & $\begin{array}{l}\text { Склад } \\
\text { сырья }\end{array}$ & Переработка & $\begin{array}{c}\text { Склад } \\
\text { готовой } \\
\text { продукции }\end{array}$ & & \\
\hline
\end{tabular}

Сбытовая концепция, обеспечивающая снижение общих затрат на реализацию сельскохозяйственной и пищевой продукции, управление товарными потоками в аграрном бизнесе

\begin{tabular}{|c|c|c|c|c|c|c|c|}
\hline $\begin{array}{c}\text { Товаропроводящая } \\
\text { сеть, 1950-е годы }\end{array}$ & - & - & - & - & - & + & + \\
\hline $\begin{array}{c}\text { Субсектор, 1970- } \\
1980-е \text { годы }\end{array}$ & - & - & - & - & + & + & + \\
\hline $\begin{array}{c}\text { Товаропроводящая } \\
\text { цепочка, 1980-е } \\
\text { годы }\end{array}$ & - & - & + & + & + & - & + \\
\hline
\end{tabular}

Потребительская концепция рассматривается как интегральный инструмент управления и координации спроса и предложения на конкретное сельскохозяйственное сырье и продукты питания, поставляемые в определенное место и в заданный период времени

\begin{tabular}{|c|c|c|c|c|c|c|c|}
\hline $\begin{array}{c}\text { Цепочка ценности } \\
\text { Портера, } \\
1985 \text { г. }\end{array}$ & - & - & + & + & + & + & + \\
\hline $\begin{array}{c}\text { Глобальная } \\
\text { товарная цепочка, } \\
1994 \text { г. }\end{array}$ & - & - & + & + & + & + & $+*$ \\
\hline $\begin{array}{c}\text { Сетевая цепочка, } \\
1985 \text { г. }\end{array}$ & - & + & + & + & + & + & + \\
\hline $\begin{array}{c}\text { Инклюзивная } \\
\text { бизнес-модель, } \\
2005 \text { г. }\end{array}$ & - & + & + & + & + & + & + \\
\hline \multicolumn{8}{|c|}{$\begin{array}{c}\text { Интегральная концепция обеспечивает формирование устойчивой продовольственной системы, } \\
\text { включающей взаимосвязанные подсистемы (кадровая, материально-техническая, технологическая, } \\
\text { информационная, финансовая, научная и др.), а также виды экономической деятельности по производству, } \\
\text { переработке, распределению и потреблению сельскохозяйственной продукции и продуктов питания, } \\
\text { объединенных едиными принципами }\end{array}$} \\
\hline $\begin{array}{c}\text { Продовольствен- } \\
\text { ная система, } 2008 \text { г. }\end{array}$ & + & + & + & + & + & + & + \\
\hline $\begin{array}{c}\text { Ландшафтная } \\
\text { система, } 2010 \text { г. }\end{array}$ & + & + & + & + & + & + & + \\
\hline
\end{tabular}

* Предусматривает выход на внутренний и внешний рынки.

Примечание. Участие субъекта в продовольственной системе отмечено знаком (+).

Источник. Авторская разработка.

транспортировки и складирования продовольствия (табл. 1):

- каждый из представленных научных подходов характеризуется количеством участников продовольственной системы, специфичными методами организации производства и продвижения сельскохозяйственной продукции на рынок, уровнем взаимодействия компаний, эффективностью работы с органами управления;

- преимуществом сбытовой концепции стало применение отдельных производственно-сбытовых функций для уменьшения затрат при транспортировке и склади- ровании аграрной продукции, что способствовало созданию предпосылок развития агропродовольственной отрасли, оценке товаропроводящих цепочек на уровне отдельных фирм (закупки, трансформация и дистрибуция) и отдельных ее составляющих, например системы обеспечения прослеживаемости продукции ${ }^{15}$ (Hesselink, Diaz, Rutgers, Scotton, Veldmann, 2006);

${ }^{15}$ Haggblade S., Gamser M. 1991. A Field Manual for Subsector Practitioners. GEMINI Tools for Microenterprise Programs: Nonfinancial Assistance Section. Washington, DC: Development Alternatives Inc. 96 p. 
- потребительская концепция рассматривается как интегральный инструмент управления и координации спроса и предложения на конкретные сельскохозяйственное сырье и продовольствие, поставляемые в определенное место и в заданный период времени. Ее сущность состоит в проведении систематической оценки поставляемой аграрной продукции на рынок с точки зрения потребителей, определении важности продуктовых рынков в цепочке основных продовольственных товаров, в том числе и с высокой добавленной стоимостью. В совокупности такой подход позволяет снизить общий уровень расходов на реализацию продукции, а в отдельных случаях при изменении схемы транспортировки затраты на складирование и содержание запасов $^{16}$ (Porter, Kramer, 2011; Gereffi, Korzeniewicz, 1994; Lazzarini, Chaddad, Cook, 2001);

- развитию интегральной концепции способствовали глобализация и регионализация мировой экономики, интернационализация национальных хозяйственных связей, решение проблем экономического, социального и экологического характера, в первую очередь, в части использования природных ресурсов (сохранение экосистем) за счет сочетания географических, природных и социально-экономических элементов $^{17}$ (Ericksen, 2008; Sayer, Buckner D., Erickson, Klopfenstein, Macken, Loy, 2013; Ильина, 2012; Кондратенко, 2019; Лагодич, 2015).

Учитывая их многообразие, мы систематизировали и обосновали следующие классификационные признаки УПС ${ }^{18}$ (Ericksen, 2008; Ingram, 2011; Ильина, 2012; Шпак, Киреенко, Байгот, Кондратенко, 2015):

${ }^{16}$ Kubzansky M., Cooper A., Barbary V. 2011. Promise and Progress market-based solutions to poverty in Africa. Monitor Inclusive Markets. PP. 1-28.

${ }^{17}$ Киреенко Н.В. 2009. Канальное распределение сельскохозяйственной продукции и продовольствия: теоретический аспект. Государственное регулирование экономики и повышение эффективности деятельности субъектов хозяйствования: материалы V Международной научно-практической конференции. Минск: Академия управления при Президенте Республики Беларусь. С. 292-294.

18 Haggblade S., Gamser M. 1991. A Field Manual for Subsector Practitioners. GEMINI Tools for Microenterprise Programs: Nonfinancial Assistance Section. Washington, DC: Development Alternatives Inc. 96 p.
- по географии охвата функционируют глобальные (экономические отношения между производителями, посредниками и потребителями сельскохозяйственного сырья и продуктов питания, а также национальными регуляторами международной торговли продовольственными товарами), региональные (между странами одного региона) и локальные подсистемы (территориальные объединения радиусом от 50 до 100 км с центрами в крупных городских образованиях, которые в условиях достижения сбалансированности являются саморегулируемыми структурами, способными самостоятельно обеспечивать собственное население продуктами питания и аккумулирующими на своей территории необходимую для этого производственную и перерабатывающую инфраструктуру агропродовольственной сферы, поддерживаемую платежеспособным спросом на сельскохозяйственную продукцию);

- по методам и системам ведения сельского хозяйства существуют традиционные (интенсивные), органические (природный или экологический) и смешанные подсистемы, позволяющие предложить потребителям широкий ассортимент аграрной продукции, обеспечивающий удовлетворение их потребностей и запросов в полном объеме;

- по сегментации продовольственного рынка выделяются масштабные и нишевые подсистемы (ориентация на полный или ограниченный сегмент покупателей и вытеснение конкурентов за счет более низких издержек производства и/или предложения товаров, лучше удовлетворяющих потребности покупателей);

- по функциональной направленности различают производственную, распределительную, складскую, транспортную, финансовую, информационную и другие составляющие, выполняющие основные и дополнительные функции в системе продовольственного обеспечения.

Таким образом, УПС характеризуется разнообразным количеством объектов и субъектов агропромышленного комплекса, деятельность которых направлена на решение производственных, социально-экономических и экологических проблем, а также включает продовольственную безопасность, 
здравоохранение, питание, занятость, научные исследования, образование, охрану окружающей среды и др.

\section{Современные тенденции развития системы продовольственного обеспечения в государствах - членах Евразийского әкономического союза}

Агропродовольственная сфера является одним из ключевых направлений государств - членов Евразийского экономического союза, обеспечивающая продовольственную безопасность, влияющая на макроэкономическое развитие и устойчивое функционирование сельских территорий. Продовольственная система Союза развивается с учетом национальных социально-экономических приоритетов стран, на основе проводимой согласованной (скоординированной) агропромышленной политики ${ }^{19}$ и характеризуется следующими современными особенностями.

1. Евразийский экономический союз включает пять государств-членов ${ }^{20}$, которые занимают более 20,2 млн кв. км (14\% мировой суши) с населением 184,3 млн чел. Анализ показал, что, исходя из достигнутых к настоящему времени параметров и тенденций социально-экономического развития Союза, аграрный рынок и продовольственную систему можно рассматривать как развивающиеся, демонстрирующие положительную динамику. Если в январе-ноябре 2020 г. наблюдалось снижение основных социально-экономических показателей ЕАЭС, то по производству продукции сельского хозяйства отмечался рост (табл. 2): за 2015-2019 гг. - на 11\%, а за 10 месяцев 2020 г. - на 3,0\%. Драйвером роста производственных показателей стали зерновые и зернобобовые культуры, масло растительное, мясо птицы, сахар и сыры.

2. Продовольственные системы государств - членов ЕАЭС формируются под влиянием внутренних и внешних факто-

19 Договор о Евразийском экономическом союзе. URL: https://pravo.by/document/?guid $=3871 \& \mathrm{p} 0=\mathrm{F} 01400176$; O Концепции согласованной (скоординированной) агропромышленной политики государств - членов Таможенного союза и Единого экономического пространства. URL: https://pravo.by/document/?guid=3871\&p0=F91300219

${ }_{20}$ Республика Армения (с 02.01.2015 г.), Республика Беларусь (с 01.01.2015г.), Республика Казахстан (с 01.01.2015 г.), Кыргызская Республика (с 12.08.2015 г.), Российская Федерация (с 01.01.2015г.). ров, которые оказывают существенное влияние на конъюнктуру продуктовых рынков Союза, формирование конкурентной среды, устойчивость и доходность товаропроизводителей, обеспечение конкурентоспособности сельскохозяйственной продукции и продуктов питания на внутреннем и внешнем рынках. Одной из ведущих отраслей сельского хозяйства Армении является животноводство, на долю которого в течение последних лет приходится почти 40\% валовой продукции аграрного сектора. В стране имеется большой потенциал для развития органического сельского хозяйства. Беларусь занимает 4-е место в мировом экспорте льноволокна, 7-е место - молочных продуктов, входит в двадцатку стран-экспортеров сахара и говядины; Россия - 1-е место в мировом экспорте пшеницы, является лидером в поставках масложировой продукции, рыбы и морепродуктов. Казахстан обладает крупным аграрным потенциалом по производству зерна, мясной и молочной продукции. По поголовью лошадей, овец, коз, молочных коров республика входит в десятку мировых лидеров, а по производству кумыса находится на 1-м месте в мире, конины - 3-м, каракуля - на 4-м месте. В Кьръызстане сельское хозяйство является ведущей отраслью национальной экономики. В стране имеются благоприятные условия для производства таких конкурентоспособных видов продукции, как тонкорунная шерсть, хлопок, сухофрукты, виноград, овощи, бахчевые (дыня и арбуз).

3. В то же время страны существенно дифференцированы по внутренним социально-экономическим условиям, аграрному потенциалу, уровню потребления населением основных пищевых продуктов, самообеспеченности продовольствием (в Беларуси последний показатель равен 90\%, России - 88, Казахстане - 84, Кыргызстане - 82, Армении $-73 \%)$. В рейтинге стран мира по уровню продовольственной безопасности по итогам 2019 г. государства - члены ЕАЭС распределились следующим образом: Беларусь 36-е место, Россия - 42-е, Казахстан - 48-е место. Армения и Кыргызстан не учитывались $^{21}$. В то же время, по оценке Евразий-

\footnotetext{
${ }^{21}$ URL: http:// https://foodsecurityindex.eiu.com/Index
} 
Таблица 2

Основные социально-экономические показатели ЕАЭС за 2015-2020 гг., \% к соответствующему периоду предыдущего года

\begin{tabular}{|c|c|c|c|c|c|c|}
\hline \multirow{2}{*}{ Показатель } & \multirow{2}{*}{ ЕАЭС } & \multicolumn{5}{|c|}{ В том числе } \\
\hline & & Армения & Беларусь & Казахстан & Кыргызстан & Россия \\
\hline \multicolumn{7}{|c|}{2015 г. } \\
\hline Валовой внутренний продукт & 97,0 & 105,3 & 96,2 & 101,2 & 105,9 & 96,3 \\
\hline $\begin{array}{l}\text { Промышленное } \\
\text { производство }\end{array}$ & 96,6 & 105,2 & 93,4 & 98,4 & 95,6 & 96,6 \\
\hline $\begin{array}{l}\text { Производство продукции } \\
\text { сельского хозяйства }\end{array}$ & 103,0 & 111,7 & 97,2 & 104,4 & 106,2 & 103,0 \\
\hline $\begin{array}{l}\text { Инвестиции в основной } \\
\text { капитал }\end{array}$ & 94,0 & 86,5 & 88,0 & 104,3 & 99,7 & 93,0 \\
\hline $\begin{array}{l}\text { Объем выполненных } \\
\text { строительных работ }\end{array}$ & 92,8 & 100,3 & 84,8 & 103,7 & 108,0 & 101,6 \\
\hline Грузооборот & 99,3 & 88,5 & 95,9 & 92,5 & 101,1 & 100,2 \\
\hline Пассажирооборот & 97,0 & 83,9 & 95,7 & 101,8 & 102,2 & 94,6 \\
\hline Оборот розничной торговли & 91,1 & 90,1 & 100,2 & 99,6 & 105,6 & 90,0 \\
\hline \multicolumn{7}{|c|}{2019 г. } \\
\hline Валовой внутренний продукт & 101,4 & 107,5 & 101,1 & 104,3 & 106,2 & 101,1 \\
\hline $\begin{array}{l}\text { Промышленное } \\
\text { производство }\end{array}$ & 102,5 & 109,0 & 101,0 & 103,8 & 106,9 & 102,4 \\
\hline $\begin{array}{l}\text { Производство продукции } \\
\text { сельского хозяйства }\end{array}$ & 103,4 & 96,2 & 102,9 & 100,9 & 102,6 & 104,0 \\
\hline $\begin{array}{l}\text { Инвестиции в основной } \\
\text { капитал }\end{array}$ & 101,9 & 104,4 & 104,3 & 109,7 & 106,3 & 100,7 \\
\hline $\begin{array}{l}\text { Объем выполненных } \\
\text { строительных работ }\end{array}$ & 101,5 & 104,3 & 100,1 & 112,9 & 100,6 & 100,6 \\
\hline Грузооборот & 100,6 & 108,9 & 94,2 & 102,2 & 104,8 & 100,6 \\
\hline Пассажирооборот & 106,5 & 108,1 & 106,7 & 104,9 & 104,9 & 107,3 \\
\hline Оборот розничной торговли & 102,0 & 107,9 & 104,2 & 105,8 & 104,1 & 101,6 \\
\hline \multicolumn{7}{|c|}{ Январь-ноябрь 2020 г. } \\
\hline Валовой внутренний продукт & 96,7 & 93,4 & 98,7 & 97,2 & 94,0 & 96,6 \\
\hline $\begin{array}{l}\text { Промышленное } \\
\text { производство }\end{array}$ & 97,2 & 99,8 & 99,3 & 99,2 & 94,5 & 97,0 \\
\hline $\begin{array}{l}\text { Производство продукции } \\
\text { сельского хозяйства }\end{array}$ & 102,3 & 100,6 & 104,9 & 105,3 & 100,9 & 101,5 \\
\hline $\begin{array}{l}\text { Инвестиции в основной } \\
\text { капитал }\end{array}$ & 95,8 & 84,3 & 97,9 & 95,1 & 85,3 & 95,9 \\
\hline $\begin{array}{l}\text { Объем выполненных } \\
\text { строительных работ }\end{array}$ & 100,5 & 99,2 & 97,5 & 112,1 & 73,7 & 99,7 \\
\hline Грузооборот & 94,7 & 98,2 & 93,8 & 96,1 & 81,4 & 94,6 \\
\hline Пассажирооборот & 51,3 & 32,4 & 66,9 & 38,0 & 56,6 & 55,0 \\
\hline Оборот розничной торговли & 95,9 & 83,4 & 102,0 & 95,0 & 82,6 & 95,9 \\
\hline
\end{tabular}

Источник. URL: http://www.eurasiancommission.org/ru/act/integr_i_makroec/dep_stat/econstat/Documents/ Analytics/indicators201512.pdf; URL: http://www.eurasiancommission.org/ru/act/integr_i_makroec/dep_stat/ econstat/Documents/Analytics/indicators201912.pdf; URL: http://www.eurasiancommission.org/ru/act/ integr_i_makroec/dep_stat/econstat/Documents/Analytics/indicators2020_11.pdf

ской экономической комиссии (далее - ЕЭК), в 2020-2021 гг. ожидается достижение уровня самообеспеченности более 97\% практически по всем продовольственным товарам, рост взаимной торговли составит 15,8\%, экспорт в третьи страны вырастет на 11,5\%, импорт сократится на $12,2 \% 22$.

${ }^{22}$ URL: https://www.belta.by/economics/view/v-eekne-vidjat-predposylok-dlja-problem-s-prodovolstviem-vsluchae-vtoroj-volny-covid-19-409853-2020/ 
4. Субъекты агропродовольственной системы получают доступ на общий аграрный рынок ЕАЭС, на котором обеспечивается справедливая конкуренция, применяются единые требования к качеству и безопасности продукции, скоординированные действия в области развития биржевой торговли ${ }^{23}$ и экспортного потенциала сельскохозяйственной продукции и продовольствия $^{24}$, гарантируется защита интересов производителей на внутреннем и внешнем рынках, вкладываются значительные средства в развитие потенциала АПК на инновационной основе. Вместе с тем распространенными во всех государствах-членах остаются ситуации, когда национальные производители и экспортеры недополучают прибыль, что отрицательно сказывается на устойчивости функционирования АПК и продовольственной системы в целом.

5. Пандемия COVID-19 стала глобальным кризисом, который оказал и продолжает оказывать негативное влияние на функционирование агропродовольственного сектора разных стран. Государства - члены Союза выработали и приняли комплекс национальных мер по обеспечению достаточного объема внутренних запасов и регулированию цен на основные продукты питания, а также внесли определенные изменения в торговую политику за счет предоставления сельскохозяйственных кредитов и финансовых средств (Армения, Казахстан, Кыргызстан), осуществления административного контроля над ценами и рыночных интервенций (Беларусь, Кыргызстан, Российская Федерация), оказания социальной поддержки уязвимым группам населения для доступа к продовольствию $(\text { Кыргызстан })^{25}$.

Несмотря на трудности, обусловленные эпидемиологической ситуацией, внутренний спрос на продукты питания в государствах членах ЕАЭС не уменьшился. При этом наблюдался рост экспортных поставок продукции АПК с территории Союза на рынки третьих стран. Важным фактором является своевременное принятие национальных антикри-

${ }^{23}$ URL: http://www.eurasiancommission.org

${ }^{24}$ Там же.

25 Ситуация на продовольственном рынке Европы и Центральной Азии и политика реагирования на пандемию COVID-19. 2020. Бюллетень ФАО. № 1. С. 1-16. зисных планов и программ развития аграрного сектора, макроэкономических и отраслевых мер по поддержке агробизнеса (в части налогообложения, финансирования льготных кредитов и др.), введение режима «зеленого коридора» для грузоперевозок сельскохозяйственной продукцией и др.

6. На наднациональном уровне продолжает формироваться система мер и механизмов экономического регулирования развития АПК, в том числе принимаются совместные решения в условиях пандемии COVID-19 (например, введение временного запрета на экспорт различных пищевых продуктов из стран ЕАЭС (с 31.03.2020 г. до 30.06.2020 г. $)^{26}$. Проводится работа в рамках перечня чувствительных сельскохозяйственных товаров, в отношении которых осуществляется взаимное предоставление планов (программ) развития производства ${ }^{27}$. Создаются равные условия для совместных фундаментальных и прикладных инновационных исследований государствами членами Союза в аграрной сфере ${ }^{28}$, направленных на создание новейших методов селекции и разведения, передовых технологий производства конкурентоспособной сельскохозяйственной продукции с высокой добавленной стоимостью, а также формирование нормативно-правовой базы, стимулирующей возможности трансферта и коммерциализации агротехнологий ${ }^{29}$.

В целом страны проводят работу в направлении учета взаимных интересов, развития системы государственной поддержки аграрной сферы и нормативно-законодательной базы по обеспечению свободного продвижения товаров, снятию барьеров

${ }^{26}$ Рис, гречиху, просо, муку грубого помола, гранулы из зерна злаков, гречневое зерно, готовые пищевые продукты из гречки, дробленые и недробленые соевые бобы, семена подсолнечника.

27 О перечне чувствительных сельскохозяйственных товаров, в отношении которых государствами - членами Евразийского экономического союза осуществляется взаимное предоставление планов (программ) развития производства, и реализации пункта 2 статьи 95 Договора о Евразийском экономическом союзе от 29 мая 2014 года: решение Совета Евразийской экономической комиссии, 12 февраля 2016 г., № 66. URL: http://www.eurasiancommission.org

28 URL: http://www.eurasiancommission.org/ru/act/ prom_i_agroprom/dep_agroprom/Pages/niokr.aspx

${ }^{29}$ URL: http://eec.eaeunion.org/ru/act/dmi/workgroup/ materials/Documents/Стратегические\%20направления\%20фор-

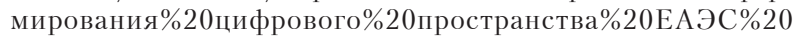
(проект).pdf 
во взаимной торговле. Однако остаются проблемы, оказывающие существенное влияние на функционирование АПК и продовольственных систем государств - членов ЕАЭС, а именно:

высокий уровень зависимости внутреннего рынка стран Союза от импорта селекционных и генетических ресурсов (особенно высокая доля ввоза семян сахарной свеклы, подсолнечника, кукурузы, рапса, овощей и даже картофеля; основная доля импорта племенной продукции приходится на крупный рогатый скот, инкубационное яйцо и птицу);

недостаточно развито производство кормов и кормовых добавок для животноводства и аквакультуры (ежегодно на закупки этой продукции тратится свыше 1 млрд долл. США);

страны Союза зависимы и от импорта отдельных видов продовольствия (определенные виды фруктов и ягод, детского питания и др.);

высокий уровень расходов на продукты питания из бюджета домохозяйств: в Кыргызстане и Казахстане - 47-49\%, Армении и Беларуси - 38-40, России - 30\%. Для сравнения в Великобритании эта статья расходов бюджета семей составляет $11 \%$, в Германии - $12 \%$;

недостаточное развитие совместной внутренней продовольственной и внешнеторговой инфраструктуры, что сдерживает маркетинговый и логистический потенциал субъектов АПК. В рейтинге эффективности логистики (Logistics Performance Index, 2018) государства - члены Союза распределились следующим образом: Казахстан (71 место), Россия (75), Армения (92), Беларусь (103), Кыргызстан (109 место) ${ }^{30}$. При этом торговые барьеры между странами приводят к дополнительным потерям и увеличению соответствующих издержек, которые в ЕАЭС составляют 20-25\% в конечной стоимости товаров (для сравнения среднемировой показатель находится на уровне 11\%, в Китае - 14, ЕС - 11, США и Канаде - 10\%);

остаются актуальными вопросы обеспечения коллективной продовольственной 2018 безопасности ${ }^{31}$ и формирования системы гарантированных поставок сельскохозяйственной продукции и продовольствия в рамках взаимной торговли государств членов Союза в случае наступления форсмажорных обстоятельств ${ }^{32}$.

\section{Ключевые направления формирования устойчивой продовольственной системы ЕАЭС на краткосрочную и долгосрочную перспективу}

Формирование УПС в разных странах становится одним из национальных приоритетных направлений, в том числе для тех государств, где наличие продуктов питания не воспринимается как непосредственная серьезная проблема (Австралия, Республика Беларусь, страны Европейского союза, Российская Федерация, Сингапур, США, Южная Корея, Япония и др.). Решение данного вопроса требует разработки скоординированных стратегий, учитывающих специфику ведения сельского хозяйства, функционирование действующих экологических, экономических и социальных систем, особенности кризисных и форс-мажорных обстоятельств в сфере продовольствия.

Несмотря на то, что агропродовольственный сектор ЕС характеризуется высоким уровнем применяемых технологий в сфере производства, переработки, хранения, складирования и транспортировки продукции, в январе 2020 г. странами интеграционного объединения была поставлена цель перехода к устойчивой продовольственной системе, а уже 20 мая 2020 г. приняты Стратегия по сохранению биоразнообразия и Стратегия «От фермы - к столу» ${ }^{33}$, объединяющие фермеров, бизнес и потребителей для выполнения совместной работы по предотвращению сокращения биоразнообразия и приведению продовольственных систем к мировым стандартам построения устойчивой пищевой цепи.

${ }^{31}$ URL: https://docs.eaeunion.org/pd/ru-ru/0123907/ pd_28062019_att.pdf

32 Пункт 6.2.2 проекта Стратегических направлений развития евразийской экономической интеграции до 2025 года, одобренных распоряжением Высшего Евразийского экономического совета от 19 мая 2020 г. № 1.

${ }^{33}$ URL: https://belgiss.by/the-eu-strategy-on-creatinga-safe-and-sustainable-food-system-from-farm-to-table 
Китай не в первый раз сталкивается с эпидемиями, поэтому основную задачу в регулировании продовольственной системы государство видит в осуществлении контроля за торговыми организации, в том числе и онлайндоставкой продуктов, с целью недопущения сильного повышения цен. Как показала ситуация с пандемией COVID-1934, производство сельскохозяйственной продукции в Китае осталось стабильным, а по ряду направлений даже показало умеренные темпы роста. Наметились изменения в структуре потребительских предпочтений (мясо, молоко и др.), были выявлены недостатки логистических и производственных цепочек, а также угрозы, связанные с экологическими рисками. Основными тенденциями, определяющими развитие сельского хозяйства и продовольственной системы в перспективе, будут цифровизация и повышение качества выпускаемой продукции.

Австралия как единственная страна мира, занимающая территорию целого материка, имеет высокие экономические показатели. Развитие национальной продовольственной системы основывается на высокоинтенсивном и высокотоварном сельскохозяйственном производстве, формирующем $12 \%$ ВВП страны и более 150 млрд долл. США валовой добавленной стоимости в этой отрасли. В то же время в период пандемии COVID-19 аграрные субъекты снизили уровень продовольственных запасов в торговых точках. При этом повышенный спрос на продукты питания показал необходимость поиска эффективных решений для восполнения дефицита, а также выявил недостатки современной модели обеспечения продовольствием страны.

Особенностью продовольственной системы Японии является наличие диспропорции между потребностями населения в продуктах питания и производственным потенциалом страны. Поэтому, с одной стороны, внутренний рынок открыт для импортных поставок, а с другой - ставка сделана на интенсивное развитие сельского хозяйства. Правительство Японии проводит структурные реформы, направленные на обеспечение устойчивости продовольственной системы, при

${ }^{34}$ Обзор экономических мер, применяемых странами в условиях распространения Covid-19. 2020. Москва: Фонд Росконгресс. С. 4. которой в условиях критической ситуации можно было бы в минимально короткие сроки увеличить производство риса, пшеницы, ячменя и других зерновых культур, картофеля и пр.

Для государств - членов ЕАЭС формирование УПС также выступает стратегическим приоритетом на краткосрочную и долгосрочную перспективу. Это связано с тем, что страны являются ведущими игроками на мировом агропродовольственном рынке, где возникают новые угрозы, связанные с влиянием внешних и внутренних рисков, а именно:

глобальных и геополитических, так как эффективное функционирование агропродовольственной сферы зависит от степени интеграции ЕАЭС в международную экономическую систему, которая напрямую формируется с учетом политической ситуации в государствах - торговых партнерах;

макроэкономической нестабильности как последствия замедления роста экономик государства, инвестиций, покупательной способности доходов населения;

природно-климатических, которые могут привести к сокращению объемов производства и экспорта сельскохозяйственной продукции, снижению эффективности хозяйствования, росту импорта продуктов питания;

технико-технологических, связанных с последствиями функционирования техникотехнологических систем и/или их нарушениями (пожары, изменение технологии, ухудшение качества и производительности производства, специфические риски технологии). В совокупности они могут привести к сбоям в производственных циклах, снижению качества продукции, объемов реализации на внутреннем и внешнем рынках и др.;

внешнеторговых (например, существенное изменение конъюнктуры мирового агропродовольственного рынка; концентрация и монополизация экспорта сырья и продовольствия ведущими странами-экспортерами и усиление на рынке их доминирующих позиций; ужесточение ветеринарных, фитосанитарных, технических требований к сельскохозяйственной продукции и продуктам питания в странах - основных торговых партнерах и др.);

социальных (а именно: невысокий уровень жизни в сельской местности; урбани- 
зация населения; отсутствие альтернативных источников занятости; нестабильная демографическая ситуация; недостаточная поддержка развития сельских территорий).

Управление указанными рисками должно осуществляться мерами согласованной агропромышленной политики ЕАЭС, включающими: стратегическое планирование в рамках видов экономической деятельности; мониторинг развития агропромышленного комплекса и обеспечения коллективной продовольственной безопасности; планирование и прогнозирование сбалансированности внутренних продуктовых рынков; развитие систем сельскохозяйственного страхования и страхования внешнеторговых рисков. Изучение международной практики формирования аграрной политики стран в период продовольственных кризисов ${ }^{35}$ показало использование широкого спектра мер реагирования, что позволило нам систематизировать наиболее распространенные подходы и рекомендуемые эффективные мероприятия (табл. 3).

${ }^{35}$ Пандемия COVID-19 (2020г.), кризис продовольственных цен в 2007-2008 гг. и эпидемий лихорадки Эбола (Западная Африка, 2014 г.), атипичной пневмонии (Восточная Азия, 2003 г.), ВИЧ/СПИД (Африка, 1990-е годы, 2000-е годы), чумы (Южная Азия, 1994 г.) и холеры (Латинская Америка, 1991 г.).

Таблица 3

Ключевые направления формирования согласованной агропромышленной политики государств членов ЕАЭС в период продовольственных кризисов

\begin{tabular}{|c|c|c|}
\hline $\begin{array}{c}\text { Цели согласованной } \\
\text { агропромышленной } \\
\text { политики государств - } \\
\text { членов ЕАЭС } \\
\end{array}$ & Распространенные ответные меры & $\begin{array}{l}\text { Рекомендуемые эффективные } \\
\text { мероприятия }\end{array}$ \\
\hline \multicolumn{3}{|c|}{$\begin{array}{c}\text { Формирование аграрными производителями, торговыми, транспортными, складскими организациями } \\
\text { предложения на сельскохозяйственную продукцию и продукты питания }\end{array}$} \\
\hline $\begin{array}{l}\text { Обеспечение } \\
\text { достаточности } \\
\text { продукции на } \\
\text { внутреннем рынке }\end{array}$ & $\begin{array}{l}\text { Экспортные ограничения } \\
\text { Расширение государственных } \\
\text { закупок } \\
\text { Применение товарных } \\
\text { интервенций }\end{array}$ & $\begin{array}{l}\text { Обосновывать экспортные ограничения } \\
\text { Не допускать формирования высоког о } \\
\text { уровня запасов продовольствия } \\
\text { Создавать равные условия для субъектов } \\
\text { на внутреннем продовольственном рынке } \\
\text { Обеспечивать реализацию } \\
\text { международных механизмов } \\
\text { регулирования рынка }\end{array}$ \\
\hline $\begin{array}{l}\text { Гарантия безопасности } \\
\text { поставок продукции }\end{array}$ & Импортные запреты & $\begin{array}{l}\text { Обеспечить наличие и доступ к } \\
\text { продовольствию } \\
\text { Создавать благоприятные условия для } \\
\text { формирования транспортных и торговых } \\
\text { коридоров }\end{array}$ \\
\hline $\begin{array}{l}\text { Поддержание } \\
\text { товаропроизводителей, } \\
\text { в том числе мелких } \\
\text { фермеров }\end{array}$ & $\begin{array}{l}\text { Субсидии на входные ресурсы для } \\
\text { расширения сельскохозяйственного } \\
\text { производства и производства } \\
\text { продуктов питания } \\
\text { Прямые выплаты }\end{array}$ & $\begin{array}{l}\text { Обосновывать эффективность } \\
\text { субсидирования с целью обеспечения } \\
\text { волатильности рынка } \\
\text { Вырабатывать систему действенных } \\
\text { механизмов по поддержанию } \\
\text { оптимистического уровня } \\
\text { продовольственной безопасности, } \\
\text { доходности и финансовой устойчивости } \\
\text { товаропроизводителей }\end{array}$ \\
\hline \multicolumn{3}{|c|}{ Формирование и стимулирование спроса на сельскохозяйственную продукцию и продукты питания } \\
\hline $\begin{array}{l}\text { Удержание цен на } \\
\text { приемлемом уровне для } \\
\text { потребителей }\end{array}$ & $\begin{array}{l}\text { Снижение импортных тарифов } \\
\text { Контроль внутренних цен } \\
\text { (государственное регулирование, } \\
\text { административный контроль и } \\
\text { др.) }\end{array}$ & $\begin{array}{l}\text { Не допускать чрезмерного накопления } \\
\text { импорта } \\
\text { При возможности обеспечивать } \\
\text { снижение импортных тарифов } \\
\text { Обосновывать систему ценового } \\
\text { регулирования и ее обсу ждение со всеми } \\
\text { субъектами рынка (вне зависимости от } \\
\text { формы собственности) }\end{array}$ \\
\hline $\begin{array}{l}\text { Поддержание } \\
\text { потребителей } \\
\text { с низким уровнем } \\
\text { дохода }\end{array}$ & $\begin{array}{l}\text { Денежные переводы } \\
\text { Внутренняя продовольственная } \\
\text { помощь }\end{array}$ & $\begin{array}{l}\text { Не вводить количественные о граничения } \\
\text { на денежные переводы } \\
\text { Расширять практику применения } \\
\text { внутренней продовольственной помощи }\end{array}$ \\
\hline
\end{tabular}

Источник. Авторская разработка. 
Анализ показал, что антикризисные механизмы в продовольственной системе должны быть направлены на устранение фактического, а не предполагаемого дисбаланса между спросом и предложением на аграрную продукцию. Приоритетность поставок дефицитных видов сельскохозяйственного сырья и продовольствия в страны - партнеры по ЕАЭС с учетом их производственной специализации позволит упреждать угрозы на внутренних рынках, обусловленные указанными рисками. Создание благоприятных условий правового, организационно-технического, экономического, финансового характера по формированию транспортных и торговых коридоров может стать основой стабильных поставок продуктов питания и способствовать обеспечению коллективной продовольственной безопасности.

В развитие этого государства - члены ЕАЭС должны разрабатывать совместные прогнозы и программы их выполнения, предусматривающие обеспечение сбалансированности общего рынка, использование потенциала стран в целях развития взаимных торговых отношений, ориентирование аграрного бизнеса на создание новых перспективных производств, совместных объектов сбытовой инфраструктуры. При этом необходимо на постоянной основе проводить мониторинг национальных и региональных рынков, конъюнктуры внутренних и внешних цен, маркетинговый анализ изменения потребностей потребителей сельскохозяйственной продукции с учетом эластичности спроса по цене и доходу, вносить соответствующие корректировки в производственную стратегию субъектов экономической деятельности.

Ситуация с пандемией COVID-19 еще раз показала, что все участники производственно-сбытовой цепи должны быть готовы к оперативной выработке и принятию антикризисных мер реагирования. В этих условиях возрастает роль информационнокоммуникационных и цифровых технологий в агропродовольственной сфере. На международном уровне эффективно функционирует Глобальная система информирования и раннего предупреждения (GIEWS) ${ }^{36}$, которая на постоянной основе отслеживает спрос и предложение продовольствия и другие ключевые показатели, необходимые для оценки уровня всеобщей продовольственной безопасности во всех странах мира. По запросам национальных органов GIEWS помогает государствам в сборе информации по оценке посевов и продовольственного обеспечения посредством специальных миссий, организуемых FAO совместно со WFP. В совокупности это позволяет укреплять национальный потенциал в использовании информации о состоянии и развитии продовольственной системы.

Внедрение аналогичного подхода на уровне ЕАЭС возможно в рамках подсистемы агропромышленного комплекса, которая функционирует как составная часть интегрированной информационной системы Союза (решение Коллегии ЕЭК от 31 января 2017 г. № 18) и обеспечивает взаимодействие ${ }^{37}$ :

с информационными системами уполномоченных органов государств-членов (национальные статистические комитеты, министерства сельского хозяйства);

подсистемами интеграционного сегмента ЕЭК интегрированной системы в части ведения общих информационных ресурсов; учетными системами субъектов хозяйствования (дополнительно предусматривая законодательство государства-члена).

Таким образом, в соответствии со стратегической целью интеграционного формирования в отношении продовольственной системы Союза должен применяться комплекс мер:

1) общего организационного характера, основанных на нормативно-правовой базе и направленных на укрепление согласованной агропромышленной политики, создание базиса конкурентоспособности государств - членов ЕАЭС, среди которых выделены: повышение эффективности мер государственной поддержки, совершенствование механизмов регулирования общего аграрного рынка и экспортной политики, обеспечение санитарных, фитосанитарных и ветеринарных (ветеринарно-санитарных) мер, развитие научного и инновационного

${ }^{36}$ URL: http://www.fao.org/giews/background/ru/

${ }^{37}$ URL: http://www.eurasiancommission.org 
потенциала АПК, интегрированной информационной системы внешней и взаимной торговли;

2) прямого содействия организациям сельского хозяйства и обрабатывающей промышленности (резидентам стран ЕАЭС) в осуществлении ими экспортной деятельности, суть которых заключается в совершенствовании механизмов финансовой поддержки сельского хозяйства (кредитование, страхование, налогообложение);

3) направленных на формирование спроса и стимулирование экспорта аграрной продукции на территории ЕАЭС и третьих стран, предусматривающих маркетинговую и информационную поддержку товаропроизводителей, развитие межгосударственного сотрудничества в области инфраструктурного обеспечения продовольственного рынка, формирование интегрированного товарного биржевого рынка.

Исследование показывает важность и необходимость формирования УПС, основной целью которых является обеспечение населения конкретной страны достаточным количеством продовольствия, в том числе в условиях форс-мажорных обстоятельств. Установлено, что эффективность функционирования национальной и мировой продовольственной системы зависит от взаимодействия: внутренней и международной торговли, охватывающей сферы продовольственного комплекса, вывоза капитала и технологий, связанных с развитием аграрного бизнеса; взаимодействия научных исследований, образования и подготовки управленческих кадров в АПК; организации и деятельности международных организаций и межнациональных соглашений, которые определяют аспекты функционирования мирового рынка; информационной системы в условиях трансформации экономики.

Интегральная концепция обеспечивает построение УПС, которая для государств - членов ЕАЭС в краткосрочной и долгосрочной перспективе должна базироваться на экономическом состоянии АПК стран, учете национальных особенностей социально-экономического развития, торго- вых взаимоотношений, законодательства и международных обязательств, эффективном использовании потенциала взаимной и внешней торговли для наиболее полного удовлетворения потребителей сельскохозяйственной продукции и продуктов питания. Наряду с этим согласованная агропромышленная политика ЕАЭС должна включать комплекс антикризисных мер и механизмов по продовольственному обеспечению внутреннего рынка и стимулированию спроса на данную продукцию, а также совместные мероприятия по решению возникающих проблем в условиях форс-мажорных обстоятельств. Ключевые направления состоят в следующем:

- единый подход к организации сельскохозяйственного и пищевого производства, функционированию продуктовых рынков (зерна, картофеля, овощей, плодов и ягод, масла растительного, сахара, мяса и мясопродуктов, молока и молокопродуктов, яиц, рыбы и рыбопродуктов);

- гибкая политика и оперативная реализация мер в области конкуренции (антимонопольного регулирования) и поддержки аграрных товаропроизводителей;

- гарантирование цен на сельскохозяйственную продукцию и сырье;

- обеспечение равновесия спроса и предложения на основных продуктовых рынках;

- оптимизация материальных и финансовых затрат на продвижение сельскохозяйственной продукции и продуктов питания на различные сегменты ЕАЭС;

- ориентация на прямые связи между поставщиками, существующими и потенциальными потребителями, исключение ненужных посредников;

- нацеленность на расширение доли рынка сбыта за счет более полного удовлетворения изменяющихся запросов покупателей ЕАЭС;

- диверсификация каналов и методов сбыта, ассортимента сельскохозяйственных и продовольственных товаров;

- учет национальных особенностей рынков всех государств - членов ЕАЭС, покупательских предпочтений, требований к качественным параметрам продукции, а также нормативно-правовых аспектов; 
- использование фондов содействия производству продукции и ее сбыту;

- совместное решение агроэкологических и социальных проблем.

\section{СПИСОК ЛИТЕРАТУРЫ (REFERENCES)}

Акимова Ю.А., Коваленко Е.Г. 2016. Системный подход к устойчивому развитию продовольственного рынка. Фундаментальные исследования. № 11-1. С. 112-116. [Akimova Yu.A., Kovalenko E.G. 2016. Systematic approach to sustainable development food market. Fundamental'nye issledovaniya. No 11-1. PP. 112-116. (In Russ.)]

Байгот М.С. 2010. Механизмы регулирования внешнеэкономической деятельности Беларуси в аграрном секторе: вопросы теории, методологии, практики. Минск: Беларуская навука. 367 с. [Baygot M.S. 2010. Mechanisms of regulation of foreign economic activity of Belarus in the agricultural sector: issues of theory, methodology, practice. Minsk: Belaruskaya navuka. 367 p. (In Russ.)]

Баринова В.А., Земцов С.П. 2019. Инклюзивный рост и устойчивость регионов России. Регион: экономика и сочиология. № 1. С. 23-46. [Barinova V.A., Zemtsov S.P. 2019. Inclusive growth and regional resilience in Russia. Region: ekonomika $i$ sotsiologiya, No 1. PP. 23-46. (In Russ.)]

Белоусов К.Ю. 2013. Современный этап эволюции концепции устойчивого развития и формирование парадигмы корпоративной устойчивости. Проблемь современной экономики. № 1. C. 47-50. [Belousov K.Yu. 2013. Contemporary stage of evolution of the sustainable development concept and formation of the corporate sustainability paradigm. Problemy sovremennoy ekonomiki. No 1. PP. 47-50. (In Russ.)]

Бельский В.И. 2018. Экономический механизм государственного регулирования сельскохозяйственного производства: теория, методология, практика. Минск: Институт системных исследований в АПК НАН Беларуси. 265 с. [Belsky V.I. 2018. The economic mechanism of state regulation of agricultural production: theory, methodology, practice. Minsk: Institut sistemnykh issledovaniy v APK NAN Belarusi. 265 p. (In Russ.)]

Берг Д.Б., Болышаков Б.Е., Гольдштейн С.Л., Попков В.В. 2007. Устойчивое экономическое развитие в условиях глобализации и экономики знаний: концептуальные основы теории и практика управления. Москва: Экономика. 295 с. [Berg D.B., Bolshakov B.E., Goldstein S.L., Popkov V.V. 2007. Sustainable Economic Development in the Context of Globalization and the Knowledge Economy: Conceptual Foundations of Theory and Practice of Management. Moscow: Ekonomika. 295 p. (In Russ.)]
Большаков Б.Е. 2011. Наука устойчивого развития. Книга I. Введение. Москва: РАЕН. 272 с. [Bolshakov B.E. 2011. Science of Sustainable Development. Book I. Introduction. Moscow: RAEN. 272 p. (In Russ.)]

Войтко И.А. 2020 Развитие системы агрострахования как фактор повышения эффективности производства и переработки льнопродукции. Агропанорама. № 3. С. 39-43. [Voitko I.A. 2020 Development of the agricultural insurance system as a factor in increasing the efficiency of production and processing of flax products. Agropanorama. No 3. PP. 39-43. (In Russ.)]

Гануш Г.И. 2019. Приоритеты развития адаптивных систем ведения сельского хозяйства Республики Беларусь в контексте эволюции аграрной теории и практики. Весці Наџыянальнай акадэміi навук Беларусі. Серыя аграрнъх навук. Т. 57. № 4. C. 418-430. [Ganush G.I. 2019. Priorities for development of adaptive systems of agriculture management in the Republic of Belarus in the context of agricultural theory and practice evolution. Vestsi Natsyyanal'nay akademii navuk Belarusi. Seryya agramykh navuk. Vol. 57. No 4. PP. 418-430. (In Russ.)]

Гусаков В.Г., Шпак А.П., Киреенко Н.В., Байгот Л.Н., Кондратенко С.А., Ахрамович В.С., Енчик Л.Т., Карпович Н.В., Лобанова Л.А., Гусаков Г.В., Макуценя Е.П., Пашкевич Д.С. 2018. Совершенствование механизмов функционирования продовольственного рынка Союзного государства Беларуси и России. Минск: Институт системных исследований в АПК НАН Беларуси. 129 с. [Gusakov V.G., Shpak A.P., Kireyenka N.V., Baigot L.N., Kondratenko S.A., Akhramovich V.S., Yonchik L.T., Karpovich N.V., Lobanova L.A., Gusakov G.V., Makutsenya E.P., Pashkevich D.S. 2018. Improving the mechanisms of functioning of the food market of the Union State of Belarus and Russia. Minsk: Institut sistemnykh issledovaniy v APK NAN Belarusi. 129 p. (In Russ.)]

Гусаков В.Г., Пилипук А.В. 2018. Конкурентоустойчивое развитие производства продуктов здорового питания в предприятиях пищевой промыцленности Беларуси. Минск: Беларуская навука. 367 с. [Gusakov V.G., Pilipuk A.V. 2018. Competitive development of healthy food production in the food industry in Belarus. Minsk: Belaruskaya navuka. 367 p. (In Russ.)]

Гусаков В.Г. 2020. Факторы и методы эффективного хозяйствования. Минск: Беларуская навука. 56 с. [Gusakov V.G. 2020. Factors and methods of effective management. Minsk: Belaruskaya navuka. 56 p. (In Russ.)]

Добросоцкий В.И. 2019. Обеспечение продовольственной безопасности в странах Евразийского экономического союза: мировой и региональные аспекты. Москва: Одинцовский филиал 
МГИМО. 128 с. [Dobrosotsky V.I. 2019. Ensuring food security in the countries of the Eurasian Economic Union: global and regional aspects. Moscow: Odintsovskiy filial MGIMO. 128 p. (In Russ.)]

Ильина 3.М. 2012. Глобальные проблемы и устойчивость национальной продовольственной безопасности. Минск: Институт системных исследований в АПК НАН Беларуси. 211 с. [Ilyina Z.M. 2012. Global challenges and sustainability of national food security. Minsk: Institut sistemnykh issledovaniy v APK NAN Belarusi. 211 p. (In Russ.)]

Ильина 3.М. 2013. Устойчивость развития продовольственной системы: методические аспекты. Весиі Нацыянальнай акадэміі навук Беларусі. Серыя аграрных навук. № 2. C. 9-19. [Ilyina Z.M. 2013. Stability of food system development: Methodological aspects. Vestsi Natsyyanal'nay akademii navuk Belarusi. Seryya agrarnykh navuk. No 2. PP. 9-19. (In Russ.)]

Коваленко Е.Г. (Ред.). 2017. Концепиия устойчивого развития продовольственного рынка. Саранск: Издательство Мордовского университета. 121 c. [Kovalenko E.G. (Ed.). 2017. The concept of sustainable development of the food market. Saransk: Izdatel'stvo Mordovskogo universiteta. 121 p. (In Russ.)]

Кондратенко С.А. 2019. Устойчивое развитие регионального агропродовольственного комплекса: теория, методология, практика. Минск: Институт системных исследований в АПК НАН Беларуси. 286 с. [Kondratenko S.A. 2019. Sustainable development of the regional agri-food complex: Theory, methodology, practice. Minsk: Institut sistemnykh issledovaniy v APK NAN Belarusi. 286 p. (In Russ.)]

Лагодич Л.В. 2015. Устойчивость развития продовольственного рынка Республики Беларусв: теория и методология. Минск: Беларуская навука. 256 с. [Lagodich L.V. 2015. Sustainability of development of the food market in the Republic of Belarus: theory and methodology. Minsk: Belaruskaya navuka. 256 p. (In Russ.)]

Сакс Дж. 1994. Рыночная экономика и Россия. Москва: Экономика. 331 с. [Sachs J. 1994. Market Economy and Russia. Moscow: Ekonomika. 331 p. (In Russ.)]

Фролов В.И. (Ред.). 2011. Методы обоснования программ устойчивого развития сельских территорий. СПб.: Санкт-Петербургский государственный архитектурно-строительный университет. 464 c. [Frolov V.I. (Ed.). 2011. Methods of substantiating programs for sustainable development of rural areas. SPb.: Sankt-Peterburgskiy gosudarstvennyy arkhitekturno-stroitel'nyy universitet. 464 p. (In Russ.)]

Шагайда Н.И., Узун В.Я. 2019. Драйверы роста и структурных сдвигов в сельском хозяй- стве России. Москва: Издательский дом «Дело» РАНХиГС. 98 с. [Shagaida N.I., Uzun V.Yа. 2019. Growth drivers and structural changes in Russian agriculture. Moscow: Izdatel'skiy dom «Delo» RANKhiGS. 98 p. (In Russ.)]

Шпак А., Киреенко Н., Байгот Л., Кондратенко С. 2015. Стратегия развития АПК Республики Беларусь в условиях обострения конкуренции на мировом продовольственном рынке. Аzрарная экономика. № 8. C. 2-8. [Shpak A., Kireyenka N., Baigot L., Kondratenko S. 2015. Development strategy of the agro-industrial complex of the Republic of Belarus in the context of increased competition in the world food market. Agramaya ekonomika. No 8. PP. 2-8. (In Russ.)]

Шпак А.П., Киреенко Н.В., Кондратенко С.А., Енчик Л.Т., Лобанова Л.А., Стешиц О.В., Мицкевич С.М., Косова А.Л. 2018. Тенденции обеспеченности населения продуктами детского питания в Республике Беларусь. Белорусский экономический журнал. № 2. C. 66-81. [Shpak A.P., Kireyenka N.V., Kandratsenka S.A., Yonchyk L.T., Labanava L.A., Stseshyts V.V., Mitskevich S.M., Kosova A.L. 2018. Trends of baby food products supply in the republic of Belarus. Belorusskiy ekonomicheskiy zhurnal. No 2. PP. 66-81. (In Russ.)]

Янбых Р.Г. 2011. О концепции устойчивого сельского развития. Экономико-политическая ситуащия в России. № 1. C. 47-50. [Yanbykh R.G. 2011. About the concept of sustainable rural development. Ekonomiko-politicheskaya situatsiya v Rossii. No 1. PP. 47-50. (In Russ.)]

Ericksen P.J. 2008. Conceptualizing food systems for global environmental change research. Global Environmental Change. Vol. 18. PP. 234-245.

Ingram J. 2011. A food systems approach to researching food security and its interactions with global environmental change. Food Security. Vol. 3. PP. 417-431.

Fuglie K. 2018. R\&D capital, R\&D spillovers, and productivity growth in world agriculture. Applied Economic Perspectives and Policy. Vol. 40. Iss. 3. PP. 421-444.

Gereffi G., Korzeniewicz M. (Eds.). 1994. Commodity Chains and Global Capitalism. New York: Praeger. $122 \mathrm{p}$.

Ghisellini P., Cialani C., Ulgiati S. 2016. A review on circular economy: The expected transition to a balanced interplay of environmental and economic systems. Journal of Cleaner Production. Vol. 114. PP. 11-32.

Hesselink M.W., Diaz O.B., Rutgers J.W., Scotton M., Veldmann M. 2006. Commercial Agency, Franchise and Distribution Contracts: Principles of European Law. Munich: Sellier European Law Publishers. $416 \mathrm{p}$.

Lazzarini S., Chaddad F., Cook M. 2001. Integrating supply chain and network analyses: The 
study of netchains. Journal on chain and network science. No 1. PP. 7-22.

Porter M., Kramer M. 2011. Creating shared value: How to reinvent capitalism and unleash a wave of innovation and growth. Harvard Business Review. Vol. 89. PP. 62-77.

Sayer K.M., Buckner C.D., Erickson G.E., Klopfenstein T.J., Macken C.N., Loy T.W. 2013. Effect of corn bran and steep inclusion in finishing diets on diet digestibility, cattle performance, and nutrient mass balance. Journal of Animal Science. Vol. 91. Iss. 8. PP. 3847-3858.

Sobal J., Kettel K., Bisogni C. 1998. A conceptual model of the food and nutrition system. Social Science \& Medicine. Vol. 47. Iss. 7. PP. 853-863.

Weltzien C. 2016. Digital agriculture - Or why agriculture 4.0 still offers only modest returns. LANDTECHNIK. Vol. 71. No 2. PP. 66-68.

In citation: Belorusskiy Ekonomicheskiy zhurnal. 2021. No 1. PP. 70-86.

Belarusian Economic Journal. 2021. No 1. PP. 70-86.

\title{
SUSTAINABLE FOOD SYSTEMS: WORLD PRACTICE AND THE EAEU MEMBER STATES EXPERIENCE
}

\author{
Natallia Kireyenka ${ }^{1}$ \\ Author affiliation: ${ }^{1}$ Institute for Advanced Training and Retraining of agribusiness specialists \\ of the educational establishment «Belarusian State Agrarian Technical University» \\ (Minsk, Belarus). \\ Corresponding author: Natallia Kireyenka (natallia_kireenko@mail.ru). \\ ABSTRACT. The article scrutinizes theoretical basis for setting up sustainable food system that \\ comprises evolution of scientific concepts, methodological principles and the all-round classification of its \\ main components. It also identifies current trends in the food supply system development among EAEU \\ member states both on national and supranational levels. With international experience considered, key \\ directions for building a sustainable food system in Union's countries in a short-term and long-term \\ framework are determined.
}

KEYWORDS: sustainability, national food system, world food system, concept of sustainable development, the Eurasian Economic Union.

JEL-code: F10, F47, Q01, Q13, Q17, Q18.

DOI: $10.46782 / 1818-4510-2021-1-70-86$

Received 14.01.2021 